\title{
Development of calcium titanium oxide coated silicon solar cells for enhanced voltage generation capacity
}

\author{
K. KATHIRVEL ${ }^{1}$, R. RAJASEKaR ${ }^{1, *}$, T. Shanmuharajan ${ }^{1}$, SAMir Kumar PAL $^{2}$, \\ P. SATHISH KUMAR ${ }^{2}$, J. SARAVANA KUMAR ${ }^{3}$ \\ ${ }^{1}$ Department of Mechanical Engineering, Kongu Engineering College, Erode 638052, Tamil Nadu State, India \\ 2 Department of Mining Enginerring, Indian Institute of Technology Kharagpur, Kharagpur 721302, West Bengal State, India \\ ${ }^{3}$ Department of Biotechnology \& Medical Engineering, Universiti Teknologi Malaysia, Kuala Lumpur 81310, Malaysia \\ Depletion of fossil fuel based energy sources drive the present scenario towards development of solar based alternative \\ energy. Polycrystalline silicon solar cells are preferred due to low cost and abundant availability. However, the power conversion \\ efficiency of polycrystalline silicon is lesser compared to monocrystalline one. The present study aims at analyzing the effect \\ of calcium titanium oxide $\left(\mathrm{CaTiO}_{3}\right)$ antireflection (AR) coating on the power conversion of polycrystalline solar cells. CaTiO 3 \\ offers unique characteristics, such as non-radioactive and non-magnetic orthorhombic biaxial structure with bulk density of \\ $3.91 \mathrm{~g} / \mathrm{cm}^{3}$. $\mathrm{CaTiO}_{3}$ film deposition on the solar cell substrate has been carried out using Radio Frequency (RF) magnetron \\ sputter coating technique under varying time durations (10 $\mathrm{min}$ to $45 \mathrm{~min}$ ). Morphological studies proved the formation of \\ $\mathrm{CaTiO}_{3}$ layer and respective elemental percentages on the coated substrate. Open circuit voltage studies were conducted on \\ bare and coated silicon solar substrates under open and controlled atmospheric conditions. $\mathrm{CaTiO}_{3}$ coated on a solar cell \\ substrate in a deposition time of 30 min showed $8.76 \%$ improvement in the cell voltage compared to the bare solar cell.
}

Keywords: calcium titanium oxide; DC magnetron sputter coating; voltage generation value; AR coated solar cell

(C) Wroclaw University of Science and Technology.

\section{Introduction}

Development of several viable renewable energy resources is in progress. Photovoltaics (PV) is one among those energy resources that provide clean and sustainable energy technology to replace fossil fuels [1]. In order to enhance the utilization of PV, power conversion efficiency (PCE) and cost factor of silicon solar cells need to be considered. Multi-crystalline silicon (mc-Si) solar cells are cheaper and account for $50 \%$ of PV modules manufactured worldwide due of their low manufacturing cost, high conversion efficiency under tropical conditions and high reliability. However, the efficiency of these photovoltaic devices is restricted by optical losses caused by the reflection of solar radiation from the top surfaces of solar cells. Hence, sputter coating method is used for AR coating which involves deposition of a layer on

*E-mail: rajasekar_cr@yahoo.com the silicon substrate. AR coating has been applied in spectacle lenses to increase the light transmission capacity and reduce the reflectance. Several splendid works on AR coating of solar cells have been reported in the literature [2]. Pure $\mathrm{ZnO}$ and hybrid $\mathrm{ZnO}-\mathrm{TiO}_{2}$ thin films were coated on glass substrates by employing sol-gel spray-spin coating technique. The effect of layer thickness on the electrical and optical properties has been analyzed. Current-voltage measurements showed higher conductivity and optical analysis revealed lower band gap of $\mathrm{ZnO}-\mathrm{TiO}_{2}$ hybrid system compared to pure $\mathrm{ZnO}$ system. The former exhibited high surface area due to the increase in film thickness [3].

Few works have been carried out by adopting sputter coating technique for solar cells. $\mathrm{NiO}_{\mathrm{x}}$ layer was deposited on both silicon wafer and indium tin oxide (ITO) coated glass substrates employing DC magnetron sputtering technique. It was observed that the morphology and roughness 
of the deposited coatings were significantly influenced by the deposition parameters. Surface roughness and surface energy were enhanced by high deposition pressure [4]. Similarly, single $\mathrm{SiO}_{2}$ layer and double $\mathrm{SiO}_{2} / \mathrm{TiO}_{2}$ layer of $\mathrm{AR}$ coatings were deposited on silicon substrates to enhance the PCE by employing RF sputtering technique. Electrical and optical characteristics of prepared specimens were examined. Lately, an improved PCE and reduced reflectance were reported [5]. Peculiar electrical and optical properties of $\mathrm{ZnO}$ were used along with $\mathrm{TiO}_{2}$ nanolayers for AR coatings in dye sensitized solar cells by utilizing a simple wet chemical route. Annealing of $\mathrm{ZnO} / \mathrm{TiO}_{2}$ was also reported and although it resulted in larger crystallite size, reduction of reflectance with increased annealing temperature was observed. PCE was significantly improved due to minimal reflectance [6].

The overall performance of monocrystalline silicon solar cells strongly depends on the environmental parameters, such as light intensity, tracking angle, cell temperature, etc. Polycrystalline solar cells work even at lesser light intensity and without a tracking system [7]. However, polycrystalline solar cells are best suited for tropical countries, like India.

India is generally tropical and features fairly hot temperatures over the year except the monsoon season. Table 1 gives the seasonal climatic conditions of Erode District, Tamil Nadu State, India, from February to June. The presented information varies with time and days.

Table 1. Seasonal climatic condition of Erode district, Tamil Nadu State, India.

\begin{tabular}{lcccccc}
\hline \multicolumn{1}{c}{ Month } & February & March & April May June \\
\hline \hline Record high $\left[{ }^{\circ} \mathrm{C}\right]$ & 37.6 & 39.7 & 40.3 & 40.4 & 38.6 \\
Average high $\left[{ }^{\circ} \mathrm{C}\right]$ & 33.3 & 35.9 & 36.7 & 35.2 & 32.2 \\
Average low $\left[{ }^{\circ} \mathrm{C}\right]$ & 19.5 & 21.3 & 23.4 & 23.5 & 22.4 \\
Record low $\left[{ }^{\circ} \mathrm{C}\right]$ & 12.8 & 15.6 & 17.8 & 16.1 & 18.3 \\
Average rainfall $[\mathrm{mm}]$ & 13.0 & 15.1 & 48 & 71.2 & 27.4 \\
Average rainy days & 1 & 1 & 3 & 4.2 & 2.7 \\
\hline
\end{tabular}

Source: India Meteorological Department

In this study, $\mathrm{CaTiO}_{3}$ was selected as AR coating material since it has unique characteristics such as non-radioactive and non-magnetic orthorhombic biaxial structure with bulk density of $3.91 \mathrm{~g} / \mathrm{cm}^{3}$, stable conductivity even at high temperature, and ability to absorb more radiation from sun. Hence, silicon substrates were coated by employing various techniques, such as sputter coating, chemical vapour deposition (CVD), spray coating, spin ion or screen printing, wet chemical route, etc. Even though so many coating techniques are available, this work deals with a sputter coating technique which has its peculiar characteristics for controlling coating properties, mechanical performance and maintaining chemical stoichiometry.

\section{Experimental}

\subsection{Coating material}

Calcium titanium oxide $\left(\mathrm{CaTiO}_{3}\right)$, belonging to the family of perovskites, was chosen as the AR coating material. It has the general structure of perovskite $\mathrm{ABX}_{3}$. In this structure, both $\mathrm{A}$ and $\mathrm{B}$ represent the metal, and $X$ signifies the oxygen molecule. The selected material has unique properties, such as (i) high photoreactivity, (ii) high oxygen ion vacancy tolerance, (iii) no magnetic field produced during charge transfer [8], (iv) stable structure even at a pressure of $120 \mathrm{GPa}$ and temperature up to $2500 \mathrm{~K}$, and (v) superconducting properties even at high temperatures [9].

\subsection{Die construction and pellitization pro- cess}

The chosen AR coating material was received in powder form. However, RF sputter coating system requires coating material in the form of solid target. Hence, the solid target was prepared by pelletization process in which a pellet with dimensions of $50.8 \mathrm{~mm}$ diameter and $5 \mathrm{~mm}$ thickness was formed by using developed mild steel (MS) die.

For this process, universal testing machine (UTM) was used to make $15 \mathrm{~g} \mathrm{CaTiO}_{3}$ powder into solid target by applying a load of $1.5 \mathrm{GPa}$ on the die. Finally, the compacted solid target was held at a temperature of $100{ }^{\circ} \mathrm{C}$ for $10 \mathrm{~min}$ in an electric furnace to remove the moisture. 


\subsection{Thin film coating}

Sputter coating machine (VR SPU-06D) was used to deposit $\mathrm{CaTiO}_{3}$ film (AR coating) on the top surface of silicon substrate. In this study, both the target and substrate were positioned at a distance of $5 \mathrm{~cm}$ by holders which were mounted inside the vacuum chamber. Thin film coating on the substrate was performed at varying time durations between $10 \mathrm{~min}$ and $45 \mathrm{~min}$ with some constant process parameters during the coating which were as follows: argon pressure of $0.7 \mathrm{GPa}$, vacuum chamber pressure $6 \mathrm{~Pa}$, and process power of $80 \mathrm{~W}$. When the vacuum pressure reached the preset value, argon gas was introduced into the chamber which acted as a working medium to deposit the target particles over the substrate.

\section{Characterization techniques}

\subsection{SEM, EDS and FESEM analyses}

SEM images were taken to assert whether the thin film coating was present on the silicon substrate by applying ICON-Quanta 200 Mark II environmental scanning electron microscope. EDS analysis was carried out on AR coated substrates to find the elemental percentage value and chemical composition of the prepared substrate by using SIGMA HV-Carl Zeiss with Bruker Quantax 200Z10 EDS detector. FESEM analysis was involved to perform crystallographic study of the developed thin film coating by employing SIGMA HV-Carl Zeiss with Bruker Quantax 200-Z10 equipment.

\subsection{Controlled atmospheric condition ex- perimental setup}

To evaluate voltage generation capacity for both AR coated and bare solar cell, this analysis was carried out in controlled atmosphere (sodium vapour lamp). Radiation and temperature were controlled to the required value due to periodic fluctuation of radiation in open atmosphere. Pyrheliometer was used to measure direct and diffuse radiation of light energy. Infrared thermometer was utilized to assess the temperature of both bare as well as AR coated solar cells.

\section{Result and discussion}

\subsection{SEM analysis and EDS measurement}

SEM and EDS analyses carried out for AR coated substrates demonstrate the $\mathrm{CaTiO}_{3}$ layer formation (Fig. 1) and presence of $\mathrm{Si}, \mathrm{Ca}, \mathrm{Ti}$ and O elements (Fig. 2) on the prepared substrate.

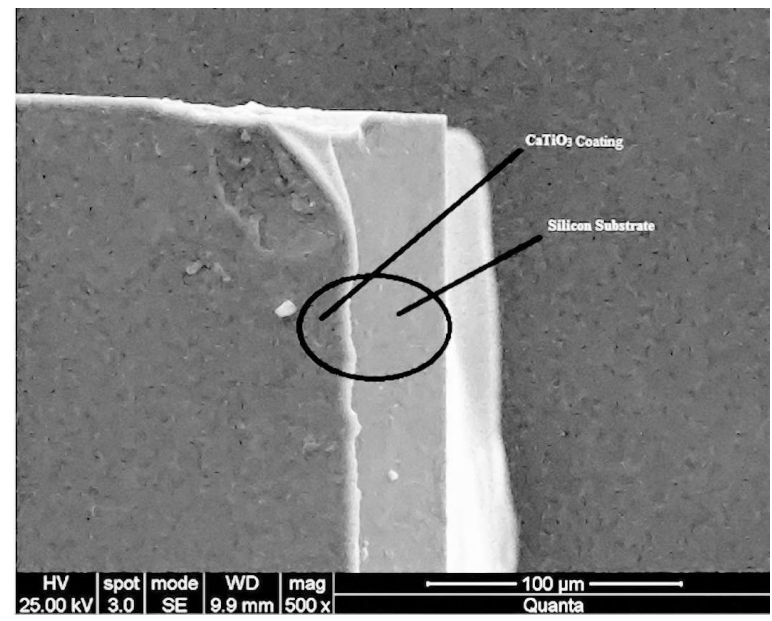

Fig. 1. SEM image showing $\mathrm{CaTiO}_{3}$ layer formation.

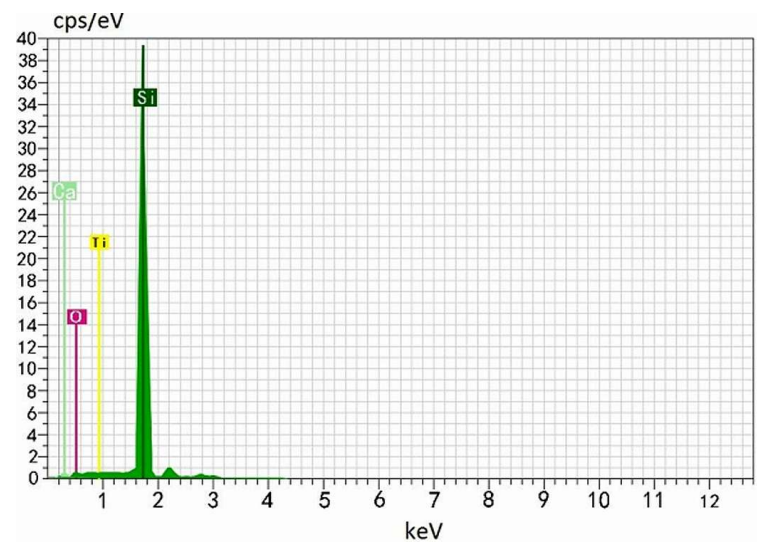

Fig. 2. EDS image showing the presence of $\mathrm{Si}, \mathrm{Ca}, \mathrm{Ti}$ and $\mathrm{O}$ elements on the substrate.

The coated substrate was examined through EDS and the obtained atomic concentrations have been depicted in Table 2. EDS confirmed the presence of $\mathrm{Si}, \mathrm{Ca}$, Ti and $\mathrm{O}$ elements and their corresponding atomic concentrations. Since AR coating was deposited at room temperature, the obtained atomic concentration of elements were unbalanced. 
From the literature, it was evident that sputter coating carried out at high temperature $\left(\geqslant 600{ }^{\circ} \mathrm{C}\right)$ may lead to achievement of balanced atomic concentrations. However, high temperature processing forms anatase phase [10] and also damages the substrate. Anatase phase generates small isolated and sharp crystals which leads to the optical losses [10].

Table 2. Amounts of $\mathrm{Si}, \mathrm{Ca}, \mathrm{Ti}$ and $\mathrm{O}$ elements on the substrate obtained through EDS analysis.

\begin{tabular}{lcc}
\hline Element & $\begin{array}{c}\text { Atomic } \\
\text { number }\end{array}$ & $\begin{array}{c}\text { Atomic concentration } \\
\text { [wt. \%] }\end{array}$ \\
\hline \hline $\mathrm{Si}$ & 14 & 46.19 \\
$\mathrm{Ca}$ & 20 & 17.23 \\
$\mathrm{Ti}$ & 22 & 20.66 \\
$\mathrm{O}$ & 8 & 15.93 \\
& & 100.00 \\
\hline
\end{tabular}

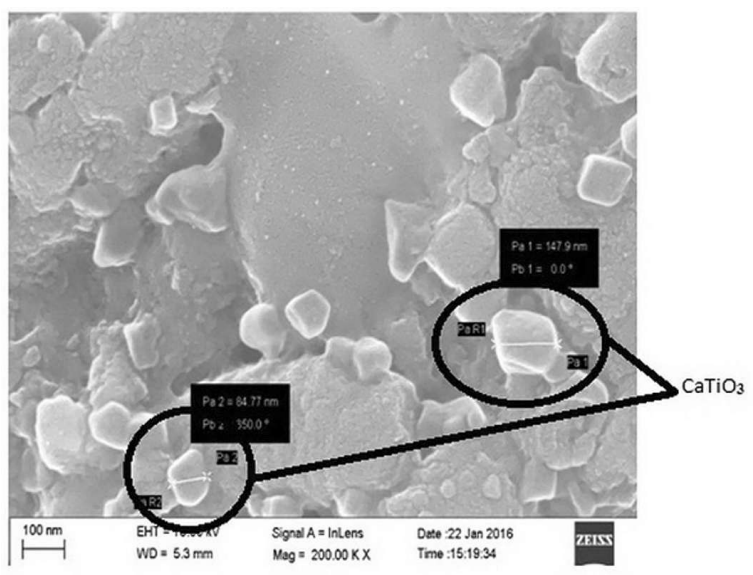

Fig. 3. FESEM image of thin film AR coated solar cell.

\subsection{FESEM analysis}

From Fig. 3, it is evident that the crystallite size of the $\mathrm{CaTiO}_{3}$ varies between $80 \mathrm{~nm}$ and $150 \mathrm{~nm}$ on the silicon substrate and that the particle size of thin film AR coated solar cell generally coincides with the particle size of raw $\mathrm{CaTiO}_{3}$ material.
4.3. Analysis of voltage generation capacity of pure and AR coated solar cell under controlled atmospheric condition

Under controlled atmospheric conditions, the bare and coated solar cells were exposed to radiation level ranging between $200 \mathrm{~W} / \mathrm{m}^{2}$ and $450 \mathrm{~W} / \mathrm{m}^{2}$ for a specified time to attain a temperature of $35{ }^{\circ} \mathrm{C}$ to $55{ }^{\circ} \mathrm{C}$. The corresponding percentage increment in cell voltage of AR coated silicon solar cells in comparison to the uncoated one is presented in Table 3.

From Table 3, it is evident that the voltage generation value of AR coated solar cells has been improved compared to the uncoated one. The increase in voltage generation of AR coated solar cell may be due to reduction in the reflection of radiation in the coated region.

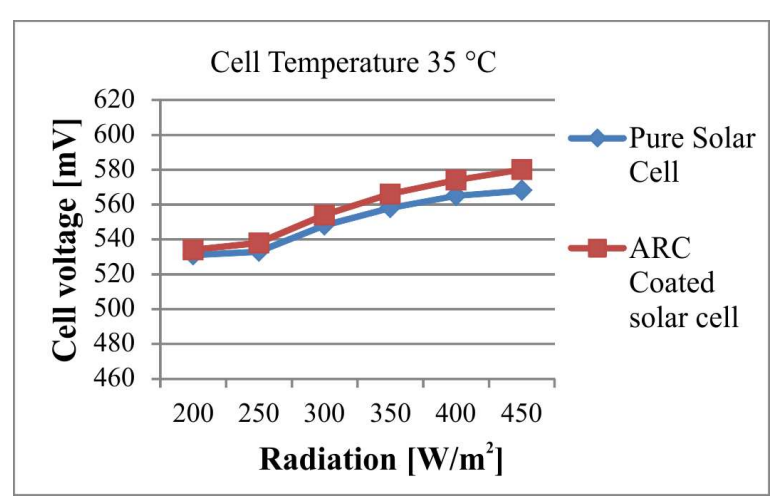

Fig. 4. Cell voltage of bare and AR coated solar cell (coating time: $30 \mathrm{~min}$ ).

A sample graph of radiation versus cell voltage of bare and AR coated solar cell is shown in Fig. 4. The cell voltage of bare and AR coated silicon substrate subsequently increases with gradual increase in radiation level. Comparatively, AR coated solar cell shows higher increment in cell voltage than the bare system.

\subsection{Analysis of voltage generation capac- ity of bare and AR coated solar cell under open atmospheric conditions}

In line with the above mentioned analysis, a similar study was conducted for solar cells under open atmospheric conditions. The cells (bare and 
Table 3. Percentage difference in cell voltage generation of AR coated solar cell compared to bare cell under controlled atmosphere conditions.

\section{S. No. Radiation from light $\left[\mathrm{W} / \mathrm{m}^{2}\right]$ \\ AR Coating time [min]}

Percentage increase in cell voltage (compared to pure silicon solar cell) in temperatures $\left[{ }^{\circ} \mathrm{C}\right]$

200

2

250

3

300

4

350

5

400

6

450

\begin{tabular}{|c|c|c|c|c|c|}
\hline & \\
\hline & 35 & 40 & 45 & 50 & 55 \\
\hline 10 & 0.6 & 1.4 & 1.8 & 2.9 & 3.6 \\
\hline 15 & 0.9 & 1.5 & 2.1 & 3.3 & 4.1 \\
\hline 20 & 1.1 & 2.0 & 3.6 & 4.1 & 5.0 \\
\hline 25 & 1.5 & 2.4 & 3.8 & 4.6 & 3.3 \\
\hline 30 & 1.8 & 2.6 & 4.0 & 5.0 & 6.2 \\
\hline 35 & 1.0 & 2.5 & 3.1 & 4.0 & 5.2 \\
\hline 40 & 0.8 & 1.2 & 2.1 & 2.3 & 2.6 \\
\hline 45 & 0.6 & 0.9 & 1.7 & 1.5 & 1.8 \\
\hline 10 & 0.9 & 1.7 & 2.3 & 4.1 & 3.8 \\
\hline 15 & 1.3 & 2.1 & 2.6 & 3.6 & 4.5 \\
\hline 20 & 1.6 & 2.7 & 3.7 & 4.7 & 5.1 \\
\hline 25 & 1.8 & 3.0 & 4.1 & 5.1 & 5.6 \\
\hline 30 & 2.3 & 3.3 & 4.5 & 5.5 & 6.6 \\
\hline 35 & 1.4 & 2.0 & 3.9 & 4.9 & 6.0 \\
\hline 40 & 1.2 & 1.8 & 2.2 & 3.1 & 3.9 \\
\hline 45 & 0.9 & 1.3 & 1.7 & 2.1 & 2.5 \\
\hline 10 & 1.1 & 2.1 & 2.9 & 3.7 & 4.4 \\
\hline 15 & 1.7 & 2.4 & 3.2 & 4.2 & 4.9 \\
\hline 20 & 3.0 & 3.1 & 3.9 & 5.2 & 5.7 \\
\hline 25 & 2.4 & 3.5 & 4.3 & 5.6 & 5.9 \\
\hline 30 & 2.7 & 3.8 & 4.9 & 6.1 & 7.0 \\
\hline 35 & 2.1 & 3.3 & 4.2 & 5.7 & 6.2 \\
\hline 40 & 1.7 & 2.7 & 3.4 & 4.3 & 5.1 \\
\hline 45 & 1.1 & 1.7 & 2.0 & 2.8 & 3.2 \\
\hline 10 & 1.4 & 2.4 & 3.1 & 4.1 & 5.0 \\
\hline 15 & 2.2 & 2.7 & 3.5 & 4.5 & 5.5 \\
\hline 20 & 2.5 & 3.6 & 5.3 & 5.8 & 6.4 \\
\hline 25 & 2.7 & 4.2 & 5.7 & 6.3 & 6.8 \\
\hline 30 & 2.8 & 4.4 & 6.0 & 6.8 & 7.2 \\
\hline 35 & 2.4 & 3.4 & 4.4 & 5.6 & 6.9 \\
\hline 40 & 2.0 & 2.8 & 3.6 & 4.5 & 5.7 \\
\hline 45 & 1.3 & 2.0 & 2.4 & 3.5 & 3.7 \\
\hline 10 & 1.6 & 2.7 & 3.6 & 4.6 & 5.3 \\
\hline 15 & 2.3 & 3.5 & 4.4 & 3.7 & 6.0 \\
\hline 20 & 2.6 & 3.7 & 5.5 & 6.3 & 7.0 \\
\hline 25 & 3.2 & 4.3 & 5.8 & 6.9 & 7.4 \\
\hline 30 & 3.3 & 4.7 & 6.3 & 7.4 & 7.9 \\
\hline 35 & 2.7 & 4.1 & 5.1 & 6.3 & 7.1 \\
\hline 40 & 2.3 & 3.1 & 4.1 & 5.5 & 6.2 \\
\hline 45 & 1.4 & 3.2 & 2.6 & 3.7 & 4.5 \\
\hline 10 & 2.1 & 3.4 & 4.1 & 5.1 & 5.8 \\
\hline 15 & 2.7 & 4.0 & 4.9 & 5.9 & 6.7 \\
\hline 20 & 3.0 & 4.6 & 5.8 & 6.6 & 7.4 \\
\hline 25 & 3.5 & 5.0 & 6.1 & 6.9 & 8.1 \\
\hline 30 & 2.9 & 5.2 & 6.5 & 7.4 & 8.8 \\
\hline 35 & 2.7 & 4.3 & 5.5 & 6.3 & 7.4 \\
\hline 40 & 2.7 & 3.8 & 5.3 & 6.2 & 6.9 \\
\hline 45 & 1.6 & 2.3 & 3.1 & 3.9 & 5.2 \\
\hline
\end{tabular}


Table 4. Percentage difference in cell voltage generation of AR coated solar cell compared to uncoated cell under open atmosphere conditions.

\begin{tabular}{|c|c|c|c|c|c|c|c|c|c|}
\hline \multirow[t]{2}{*}{ Time interval } & \multirow[t]{2}{*}{ Radiation from sun $\left[\mathrm{W} / \mathrm{m}^{2}\right]$} & \multicolumn{8}{|c|}{$\begin{array}{l}\text { Percentage increase in cell voltage (compared to } \\
\text { pure silicon solar sell) after AR coating time } \\
\text { [min]: }\end{array}$} \\
\hline & & 10 & 15 & 20 & 25 & 30 & 35 & 40 & 45 \\
\hline 10:00 & 626 & 7.2 & 7.9 & 9.1 & 10.1 & 10.3 & 7.7 & 4.2 & 1.5 \\
\hline 10:30 & 837 & 9.3 & 9.9 & 10.7 & 11.1 & 12.5 & 11.5 & 5.3 & 2.2 \\
\hline 11:00 & 985 & 10.6 & 11.6 & 13.1 & 15.4 & 16.2 & 12.4 & 5.7 & 2.7 \\
\hline 11:30 & 1004 & 11.8 & 13.2 & 13.7 & 16.7 & 19.5 & 14.2 & 6.3 & 2.8 \\
\hline 12:00 & 1081 & 13.9 & 15.7 & 19.7 & 24.7 & 27.7 & 15.0 & 6.4 & 2.8 \\
\hline $12: 30$ & 1115 & 15.0 & 18.5 & 22.5 & 23.3 & 30.3 & 14.9 & 6.7 & 3.1 \\
\hline 13:00 & 1155 & 15.9 & 19.1 & 22.5 & 25.7 & 30.8 & 16.1 & 6.9 & 3.2 \\
\hline 13:30 & 1055 & 14.4 & 16.4 & 20.1 & 21.7 & 24.6 & 16.2 & 4.4 & 2.9 \\
\hline 14:00 & 985 & 10.9 & 12.9 & 15.5 & 17.1 & 16.8 & 12.7 & 5.3 & 2.7 \\
\hline $14: 30$ & 822 & 8.9 & 9.9 & 10.2 & 10.6 & 10.8 & 5.5 & 3.8 & 2.4 \\
\hline 15:00 & 656 & 7.9 & 8.6 & 9.5 & 10.4 & 11.0 & 5.3 & 3.6 & 1.7 \\
\hline $15: 30$ & 573 & 7.3 & 8.6 & 9.9 & 10.3 & 10.5 & 4.5 & 2.5 & 1.4 \\
\hline $16: 00$ & 528 & 6.5 & 7.7 & 8.6 & 9.3 & 10.1 & 4.4 & 2.1 & 1.3 \\
\hline
\end{tabular}

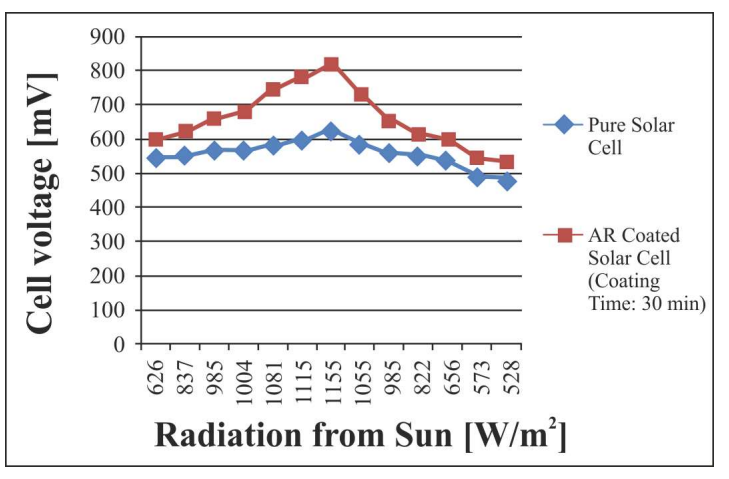

Fig. 5. Cell voltage of uncoated and AR coated solar cell fabricated in coating time of $30 \mathrm{~min}$.

AR coated) were exposed to sun light and the corresponding voltage generation capacities were observed. Voltage generation results of AR coated silicon solar cells were compared with the uncoated ones and the percentage increment in cell voltage is presented in Table 4.

From Table 4, it is evident that voltage generation of solar cells is enhanced after AR coating. The obtained trend is in accordance with the results generated under controlled atmospheric conditions. Fig. 5 shows a sample comparative plot of radiation versus cell voltage for bare and AR coated solar cell. Fig. 5 provides a clear representation relating to enhancement in cell voltage of AR coated cells compared to the uncoated one with variation in sun radiation.

$\mathrm{CaTiO}_{3}$ proved to be a potential material to enhance the voltage generation of silicon solar cells. In addition, this wider band gap material substantially reduced the hot-carrier loss and increased the value of generated voltage [11]. Maximum cell voltage was achieved for AR coating obtained in the deposition process lasting $30 \mathrm{~min}$ (Table 3 and Table 4). Further increase in coating time, more than $30 \mathrm{~min}$, resulted in the drop in voltage generation capacity. The obtained result is in agreement with the literature on this subject. Excessive deposition of coating material ultimately reduces the velocity of photons emitted from sunlight which leads to a drop in the value of generated cell voltage [12]. Based on the obtained cell voltage results, AR coating deposited for $30 \mathrm{~min}$ is the optimal one.

\section{Conclusions}

In this study, bare and AR coated solar cells were tested in both controlled and open 
atmosphere. The AR coatings were deposited on silicon substrates by using RF magnetron sputter coating technique. Under controlled atmospheric conditions, the voltage generation value of $\mathrm{AR}$ coated substrate was improved by $8.8 \%$ at the radiation of $450 \mathrm{~W} / \mathrm{m}^{2}$ compared to the bare solar cell. The test carried out at open atmospheric conditions showed a $30.8 \%$ increment in voltage generation value at the radiation of $1155 \mathrm{~W} / \mathrm{m}^{2}$. The results prove that $\mathrm{CaTiO}_{3}$ material considerably increases the voltage generation of silicon solar cells due to harvesting broader range of the solar spectrum. Meanwhile, wider band gap material also reduces the hot-carrier loss and increases the voltage generation value.

\section{Acknowledgements}

This research work was financially supported by the Science and Engineering Research Board, Department of Science \& Technology, Government of India, under the Start Up Research Grant for Young Scientist (Project Grant No. YSS/2015/001151).

\section{References}

[1] Hocine D., Belkaid M.S., Pasquinelli M., Escoubas L., Simon J.J., Rivere G.A., Moussi A., Mat. Sci. Semicon. Proc., 16 (2013), 113.
[2] Saha S., Sinha T.P., Mookerjee A., Eur. Phys. J. $B, 18$ (2000), 207.

[3] Dobrzanski L.A., SzIndLER M., JAMME, 52 (2012), 7.

[4] Awais M., Rahman M., Macelroy don J.M., Coburn N., Dini D., Vos J.G., Dowling D.P., Surf. Coat. Tech., 204 (2010), 2729.

[5] Ali K., Khan S.A., JAFri M.M.Z., Int. J. Electrochem. Sc., 9 (2014), 7865.

[6] Anderson F., Lima S., VAsconcelos I.F., CAntu L.M., Ceram. Int., 41 (2015), 9314.

[7] Chander S., Purohit A., Sharma A., Nehra S.P., DHAKA M.S., Energ. Rep., 1 (2015), 175.

[8] Moreira M.L., Paris E.C., Nascimento do G.S., Longo V.M., Sambrano J.R., Mastelaro V.R., Bernardi M.I.B., Andrés J., VAREla J.A., Longo E., Acta Mater., 57 (2009), 5174.

[9] Jin K.X., Li Y.F., WAng Z.L., PEng H.Y., Lin W.N., KYAW A.K.K., JiN Y.L., Jin K.J., SUN X.W., SocI C., WU T., AIP Adv., 2 (2012), 042131.

[10] Bockute K., Laukaitis G., Virbukas D., MilCIUS D., Mater. Sci.+,19 (2013), 1392.

[11] ZI W., ReN X.D., Ren X.P., Wei Q., GaO F., Zhong S., LiU F., Opt. Commun., 380 (2016), 1.

[12] Wu S., Han H., Tai Q., Zhang J., Xu S., Zhou C., Yang Y., Hu H., Chen B., ZhaO X.-Z., J. Power Sources, 182 (2008), 119. 